\title{
PENGARUH KOMPETENSI DAN PENGALAMAN KERJA TERHADAP KINERJA PEGAWAI DI KPP PRATAMA JAKARTA PANCORAN
}

\author{
Muhammad Rifqi Fahreza; Zackharia Rialmi; Ranila Suciati \\ Universitas Pembangunan Nasional Veteran Jakarta \\ Email korespondensi: mr.fahreza@upnvj.ac.id \\ http://dx.doi.org/10.21460/jrmb.2021.162.394
}

\begin{abstract}
ABSTRAK
Penelitian ini merupakan penelitian kuantitatif yang bertujuan untuk mengetahui pengaruh kompetensi, dan pengalaman kerja terhadap kinerja pegawai di KPP Pratama Jakarta Pancoran. Populasi pada penelitian ini ada seluruh pegawai KPP Pratama Jakarta Pancoran yang berjumlah 113 pegawai. Jumlah sampel yang digunakan pada penelitian ini sebanyak 88 pegawai dengan penggunaan rumus slovin. Data yang digunakan dalam penelitian ini adalah data primer, yaitu dengan cara penyebaran kuesioner atau angket. Teknik analisis data yang digunakan dalam penelitian ini adalah teknik analisis data kuantitatif dengan menggunakan metode statistik. Metode statistik yang digunakan adalah Partial Least Square (PLS). Hasil pengujian diperoleh hasil (1) kompetensi berpengaruh positif dan signifikan terhadap kinerja pegawai KPP Pratama Jakarta Pancoran, dan (2) pengalaman kerja berpengaruh positif dan signifikan terhadap kinerja pegawai pegawai KPP Pratama Jakarta Pancoran
\end{abstract}

Kata Kunci: kompetensi, pengalaman kerja, kinerja pegawai

\begin{abstract}
This study is a quantitative study that aims to determine the effect of competence and work experience on employee performance at KPP Pratama Jakarta Pancoran. The population in this study were all employees of KPP Pratama Jakarta Pancoran totaling 113 employees. The number of samples used in this study was 88 employees using the slovin formula. The data used in this study is primary data, namely by distributing questionnaires. The data analysis technique used in this research is the quantitative data analysis technique using statistical methods. The statistical method used is Partial Least Square (PLS). The test results obtained (1) competence has a positive and significant effect on the performance of KPP Pratama Jakarta Pancoran employees, (2) work experience has a positive and significant effect on the performance of KPP Pratama Jakarta Pancoran employees.
\end{abstract}

Keywords: competence, work experience, employee performance

\section{PENDAHULUAN}

Di era teknologi atau digital sekarang walaupun teknologi sudah berkembang sangat pesat, namun Sumber Daya Manusia (SDM) masih sangat dibutuhkan. Sumber daya manusia merupakan salah satu faktor suatu perusahaan untuk mencapai kesuksesan atau mencapai tujuannya, dengan memiliki sumber daya manusia yang kompetitif dan memiliki kemampuan yang sangat baik maka dapat memudahkan perusahaan untuk mencapai tujuannya. Dengan adanya perkembangan zaman maka sumber daya manusia dituntut untuk selalu berkembang dan mengikuti perkembangan teknologi, apalagi dengan persaingan yang ketat dan adanya pasar bebas yang telah muncul dengan adanya Masyarakat Ekonomi ASEAN (MEA) yang menuntut agar setiap perusahaan atau sumber daya manusia perlu ditingkatkan daya saingnya agar yang lebih tinggi. 
KPP Pramata Jakarta Pancoran sebagai kantor pelayanan pajak dituntut untuk selalu meningkatkan kinerjanya setiap tahunnya untuk penerimaan pajak negara agar pendapatan negara semakin meningkat dan masyarakat semakin sadar akan wajib pajak. KPP Pratama Jakarta Pancoran dalam melakukan pencarian dan perekrutan calon pegawainya yaitu melalui tes CPNS atau tes Calon Pegawai Negeri Sipil, yang di dalamnya telah terdaftar beragam calon pekerja yang berbeda tingkat pendidikan, kemampuan, dan usia.

Tabel 1. Data Pendidikan Pegawai KPP Pratama Jakarta Pancoran

\begin{tabular}{lc}
\hline Pendidikan & Jumlah \\
\hline S2 & 11 \\
\hline S1 & 37 \\
\hline Diploma 1 / 2 / 3 & 59 \\
\hline SMA / SMK & 6 \\
\hline
\end{tabular}

Sumber: Data Kepegawaian KPP Pratama Jakarta Pancoran.

Dalam KPP Pratama Jakarta Pancoran yang pegawainya berjumlah 113 pegawai memiliki latar belakang dan tingkat Pendidikan yang berbeda antara pegawainya. Pegawai KPP Pratama Jakarta Pancoran rata-rata memiliki pendidikan Diploma sebanyak 59 pegawai, dan pegawai dengan pendidikan S1 sebanyak 37 pegawai, dan memiliki sebanyak 11 pegawai dengan Pendidikan S2, dan sebanyak 6 pegawai dengan Pendidikan SMA/SMK. Dengan hal ini maka pegawai-pegawai tersebut memiliki tingkat pendidikan serta kemampuan kompetensi yang berbeda-beda dalam bekerja dan mengisi jabatan, karena pendidikan diploma lebih mengedepankan lulusan untuk siap kerja.

\begin{tabular}{ccc}
\multicolumn{3}{c}{ Tabel 2. Data Usia } \\
\hline Usia & Jumlah & Persentase \\
\hline $20-25$ & 11 & $12 \%$ \\
$26-30$ & 11 & $11 \%$ \\
$31-35$ & 30 & $31 \%$ \\
$36-40$ & 12 & $13 \%$ \\
$41-45$ & 14 & $8 \%$ \\
$46-50$ & 8 & $15 \%$ \\
$51-60$ & 10 & $10 \%$ \\
\hline
\end{tabular}

Sumber: Data Kepegawaian KPP Pratama Jakarta Pancoran.

Berdasarkan hasil wawancara terhadap bidang sumber daya manusia, maka pegawai dengan kinerja buruk yang berusia $20-21$ sebanyak 4 pegawai, usia 28- 29 sebanyak 3 pegawai, usia 30 - 32 sebanyak 3 pegawai, usia 34 - 37 sebanyak 2 pegawai, usia 45 - 49 sebanyak 2 pegawai, dan usia 52 sebanyak 1 pegawai. Berdasarkan hal tersebut maka ratarata pegawai di KPP Pratama Jakarta Pancoran memiliki jenjang umur sekitar 31-35 tahun atau dapat dikatakan sebagai usia pertengahan (middle age) atau paruh baya. Dengan rata-rata umur sekitar 31-35 maka pengalaman kerja yang dimiliki dapat digolongkan sebagai cukup atau dapat digolongkan sebagai usia produktif.

Tabel 3. Data Kinerja

\begin{tabular}{ccc}
\hline Kinerja & Jumlah & Persentase \\
\hline Baik & 13 & $16 \%$ \\
Sedang & 60 & $72 \%$ \\
Kurang & 10 & $12 \%$ \\
\hline
\end{tabular}

Sumber: Data kepegawaian KPP Pratama Jakarta Pancoran.

Menurut Sulaeman dalam (Ukkas, 2017) bahwa jika pegawai tersebut telah memiliki masa kerja atau pengalaman kerja yang tergolong sudah lama, maka dapat dikatakan bahwa pegawai tersebut semakin terampil. Karena jika pegawai memiliki keterampilan yang tinggi, maka akan memberikan dampak positif terhadap kinerjanya, seperti dalam penyelesaian pekerjaannya akan semakin cepat, dan memberikan hasil pekerjaan yang semakin berkualitas atau semakin baik. Tetapi dalam hal ini sudah tercatat beberapa penurunan kinerja akibat dari kurangnya pengalaman kerja dan kompetensi di beberapa posisi.

Jumlah pegawai KPP Pratama Jakarta Pancoran pada tahun 2019 yaitu sebanyak 83 pegawai dan kinerja pegawai yang memiliki kinerja sedang yaitu sebesar $72 \%$ atau sebanyak 60 pegawai, pegawai yang memiliki kinerja baik yaitu sebesar 16\% atau sebanyak 13 pegawai, dan yang memiliki kinerja kurang yaitu sebesar $12 \%$ atau sebanyak 10 pegawai. Selanjutnya dalam KPP Pratama Jakarta, telah terjadi penambahan pegawai pada tahun 2020 sebanyak 30 pegawai dan jika di totalkan menjadi 113 pegawai.

Setelah bertambahnya pegawai dan setelah penilaian kinerja tahunan rata-rata kinerja pegawai KPP pratama Jakarta Pancoran pada tahun 2020 adalah sedang yaitu 
sebanyak $70 \%$ atau sebanyak 79 pegawai yang kinerjanya sedang, lalu pegawai yang berkinerja baik yaitu sebesar $16 \%$ atau sebanyak 18 pegawai, dan pegawai yang berkinerja buruk atau kurang yaitu sebanyak 16 pegawai. Berdasarkan kedua grafik tersebut, maka telah terjadi penurunan kinerja yang pada 2019 pegawai yang berkinerja kurang yaitu sebanyak 10 pegawai dan pada tahun 2020 bertambah menjadi 16 pegawai.

Berdasarkan studi dan penelitian yang diteliti oleh Kolibácová (2014) bahwa kompetensi mempengaruhi kinerja pegawai secara signifikan. Sejalan dengan penelitian oleh Fransisca \& Adiputra (2019) membuktikan bahwa kompetensi bersama sama berpengaruh secara positif dan dinilai signifikan terhadap kinerja pegawai. Sama dengan yang dikemukakan menurut Gunawan, Nurwati, \& Nasrul (2017) kompetensi dan pengalaman kerja berpengaruh secara signifikan terhadap kinerja pegawai. Serta menurut Anjani \& Wirawati (2018) pengalaman kerja berpengaruh positif terhadap kinerja pegawai. Berlainan dengan penelitian oleh Hasudungan (2017) bahwa kompetensi berpengaruh tidak signifikan terhadap kinerja pegawai dan pengalaman kerja berpengaruh secara signifikan terhadap kinerja pegawai. Dari hasil penjelasan dan penafsiran dalam latar belakang tersebut dan telah didukung oleh hasil penelitian terdahulu, maka peneliti tertarik untuk melakukan penelitian dengan judul "Pengaruh Kompetensi dan Pengalaman Kerja terhadap Kinerja Pegawai di KPP Pratama Jakarta Pancoran".

\section{METODA PENELITIAN}

Penelitian ini merupakan penelitian kuantitatif. Dalam penelitian ini yang dijadikan sebagai objek atau populasi penelitian adalah pegawai KPP Pratama Jakarta Pancoran yang berjumlah 113 pegawai. Dalam penentuan ukuran dari sample dalam penelitian ini akan dilaksanakan dengan menggunakan metode atau rumus Slovin, jumlab dari sampel yang akan dipergunakan dalam penelitian ini, yakni sebesar 88,1091617934 atau mendapatkan sebesar 88 responden. Selanjutnya pengambilan datanya menggunakan angket (kuesioner) yang akan dibagikan kepada pegawai KPP Pratama Jakarta Pancoran dan diukur menggunakan skala likert. Dalam pengolahan data yang digunakan dalam penelitian ini, yaitu menggunakan aplikasi Smart PLS3.0. Teknik analisis data yang digunakan dalam penelitian ini dengan menggunakan analisis deskriptif, analisis inferensial, uji validitas, uji reabilitas, uji koefisien determinan ( $R$ Squares), dan uji hipotesis (t-parsial) dengan menggunakan tstatistik.

\section{HASIL DAN PEMBAHASAN Deskriptif Data Penelitian}

Dalam penelitian ini, pada tahap menghimpun data dengan melakukan penyebaran kuesioner sebanyak 88 kuesioner kepada responden yang sudah ditentukan oleh peneliti, yaitu pegawai KPP Pratama Jakarta Pancoran. Berikut merupakan deskripsi data dari responden yang telah ditentukan oleh peneliti.

Tabel 2. Data Responden Berdasarkan Jenis Kelamin

\begin{tabular}{lcc}
\hline \multicolumn{1}{c}{ Jenis Kelamin } & Frekuensi & Persentase \\
\hline Laki-laki & 40 & $45,5 \%$ \\
\hline Perempuan & 48 & $54,5 \%$ \\
\hline \multicolumn{1}{c}{ Total } & $\mathbf{8 8}$ & $\mathbf{1 0 0 \%}$ \\
\hline
\end{tabular}

Sumber: Data Diolah, 2021

Berdasarkan Tabel 2, pegawai berjenis kelamin laki-laki sebanyak 40 responden atau $45,5 \%$ dan yang berjenis kelamin perempuan yaitu sebanyak 48 responden atau $54,5 \%$.

Tabel 3. Data Responden Berdasarkan Usia

\begin{tabular}{lcc}
\hline Usia & Jumlah & Persentase \\
\hline$<30$ Tahun & 36 & $41 \%$ \\
\hline 31-35 Tahun & 20 & $23 \%$ \\
\hline 36-40 Tahun & 6 & $7 \%$ \\
\hline$>41$ Tahun & 26 & $29 \%$ \\
\hline Total & $\mathbf{8 8}$ & $\mathbf{1 0 0 \%}$ \\
\hline
\end{tabular}

Sumber: Data Diolah, 2021

Berdasarkan pada Tabel 3, bahwa dapat diketahui bahwa data penelitian mengenai dengan usia responden. Dari sini dapat disimpulkan bahwa responden yang memiliki usia kurang dari 30 tahun yaitu adalah sebanyak 36 responden atau sebesar $41 \%$, selanjutnya ialah yang berusia antara 31 hingga 35 tahun yaitu sebanyak 20 responden atau sebesar $23 \%$, begitu pula yang berusia 36 hingga 40 tahun yaitu sebanyak 6 Responden atau sebesar 7\%, 
dan yang sudah berusia di atas usia 41 tahun sebanyak 26 responden atau sebesar $29 \%$. Berdasarkan hal ini, maka dapat disimpulkan bahwa rata-rata pegawai di KPP Pratama Jakarta Pancoran memiliki usia rata-rata ialah kurang dari 30 tahun.

Tabel 4. Data Responden Berdasarkan Masa Kerja

\begin{tabular}{ccc}
\hline Masa Kerja & Frekuensi & Persentase \\
\hline$<10$ Tahun & 49 & $55 \%$ \\
\hline $11-15$ Tahun & 14 & 16 \\
\hline $16-20$ Tahun & 5 & $6 \%$ \\
\hline$>21$ Tahun & 20 & $23 \%$ \\
\hline Total & $\mathbf{8 8}$ & $\mathbf{1 0 0 \%}$ \\
\hline
\end{tabular}

Sumber: Data Diolah, 2021

Berdasarkan pada hasil pada Tabel 4, yaitu data penelitian mengenai tentang masa kerja yang dimiliki oleh responden atau pegawai KPP Pratama Jakarta Pancoran. Dari hasil tersebut dapat disimpulkan bahwa responden dengan masa kerja kurang dari 10 tahun yaitu sebanyak 49 pegawai atau sebesar $55 \%$, selanjutnya ialah untuk yang memiliki masa kerja 11 sampai 15 tahun yaitu sejumlah 14 pegawai atau sebesar $16 \%$, begitupula yang memiliki masa kerja 16 sampai 20 tahun adalah. Sebanyak 5 pegawai atau sebesar $6 \%$, dan yang sudah bekerja atau memiliki masa kerja lebih dari 21 tahun yaitu sebanyak 20 pegawai atau sebesar 23\%. Oleh karena itu, pegawai KPP Pratama Jakarta Pancoran telah memiliki masa kerja paling banyak ialah selama kurang lebih 10 tahun.

\section{Uji Validitas}

Data tabel pada Fornell-Larcker di atas dapat diartikan uji validitas diskriminan (discriminant validity) yang mencakup kinerja pegawai (Y) memiliki nilai sebesar 0,835 , selanjutnya kompetensi (X1) memiliki nilai sebesar 0,825, dan pengalaman kerja (X2) memiliki nilai 0,836. Berdasarkan hasil uji validitas yang telah diukur tersebut dapat disintesakan uji validitas diskriminan (discriminant validity) pada tiap variabel Kompetensi, Pengalaman Kerja, dan Kinerja Pegawai telah valid dan termasuk sudah memenuhi uji validitas diskriminan. Seperti yang telah dikemukakan (Iman, 2014, hlm. 40) yaitu bahwa untuk convergent validity dan discriminant validity jika telah memiliki skala pengukuran nilai loading sebesar 0.5 sampai 0.6 maka akan dianggap cukup, sementara jika memiliki nilai discriminant validity yang dinilai baik, maka direkomendasikan nilai AVE > 0.5.

Berdasarkan pada tabel di atas, dapat dikatakan bahwa dalam analisis data atau pengolahan data dengan discriminant validity melalui square root of Average Variance Extracted (AVE) yang terdiri dari Kinerja Pegawai (Y) yang memiliki nilai AVE sebesar 0,680, Kompetensi (X1) 0,699, dan Pengalaman Kerja (X2) 0,697. Dari hasil uji validitas terdapat kesimpulan bahwa pengukuran dalam pengujian validitas diskriminan (discriminant validity) dengan metode AVE pada variabel Kinerja Pegawai, Kompetensi, dan Pengalaman Kerja ialah dapat dikatakan baik dan telah memenuhi uji validitas diskriminan.

\section{Uji Reliabilitas}

Berdasarkan pada hasil tabel di atas, bahwa telah menunjukkan nilai dari Composite Reliability yang ada pada semua konstruk yaitu sudah berada pada > 0,7 yang berarti dapat dikatakan untuk semua konstruk pada model yang telah diestimasi telah terbukti memenuhi syarat seperti yang telah dijelaskan oleh (Iman, 2014, hlm. 41).

Tabel 5. Fornell-Lacker Criterium

\begin{tabular}{lcccc}
\hline & Kompetensi & Aengalaman \\
Kerja (X2) & $\begin{array}{c}\text { Kinerja } \\
\text { Pegawai } \\
(\mathbf{Y})\end{array}$ & $\begin{array}{c}\text { Average } \\
\text { Variance } \\
\text { Extracted } \\
\text { (AVE) }\end{array}$ \\
\hline Kompetensi (X1) & $\mathbf{0 . 8 2 5}$ & & $\mathbf{0 . 8 3 6}$ & 0.699 \\
Pengalaman Kerja (X2) & 0.805 & 0.792 & $\mathbf{0 . 8 3 5}$ & 0.697 \\
Kinerja Pegawai (Y) & 0.901 & & 0.680 \\
\hline
\end{tabular}

Sumber: Hasil Output PLS 3.0 
Karena hasil tersebut memiliki nilai Composite Reliability terendah ialah sebesar 0,933 pada konstruk Pengalaman Kerja, dan nilai Composite Reliability tertinggi ialah sebesar 0,967 pada konstruk Kinerja Pegawai. Sementara untuk variabel Kompetensi yaitu sebesar 0,959. Dengan hal tersebut maka telah ditunjukan bahwa semua variabel yang digunakan penelitian ini dianggap reliabel terhadap setiap konstruknya yaitu pads variabel Kompetensi, Pengalaman Kerja, dan Kinerja Pegawai

Berdasarkan penjelasan yang dikemukakan oleh Iman (2014, hlm. 41), maka nilai yang direkomendasikan dan disarankan untuk Croncbach Alpha yaitu sebesar > 0,7 dan pada tabel di atas telah dan sudah menunjukkan bahwa nilai Cronbach Alpha yang terdapat pada semua konstruk, sudah berada di atas 0,7. Nilai Cronbach Alpha pada table tersebut untuk nilai terendah adalah sebesar 0,914 untuk konstruk pengalaman kerja dan untuk nilai tertinggi adalah sebesar 0,963 yaitu untuk konstruk atau variabel kinerja pegawai. Berdasarkan hal ini maka telah ditunjukkan bahwa semua variabel dapat dikatakan sudah reliabel dan sangat reliabel untuk konstruknya masing-masing.

Tabel 6. Composite Reliability (CR)

\begin{tabular}{lcc}
\hline & Composite Reliability (CR) & Cronbach Alpha \\
\hline Kompetensi (X1) & 0.959 & 0.953 \\
Pengalaman Kerja (X2) & 0.933 & 0.914 \\
Kinerja Pegawai (Y) & 0.967 & 0.963 \\
\hline
\end{tabular}

Sumber: Hasil Output PLS 3.0

\section{Uji Koefisien Determinasi}

Data dan hasil pengolahan pada tabel di atas dapat diartikan kontribusi pengaruh kompetensi dan pengalaman kerja yakni sebesar 0,824 atau sebesar $82,4 \%$ terhadap kinerja pegawai, sedangkan untuk sisanya sebesar $17,6 \%$ dapat dipengaruhi variabel lain yang tidak diikutsertakan dalam penelitian ini.

\begin{tabular}{ccc}
\multicolumn{3}{c}{ Tabel 7. R Square } \\
\hline & $\begin{array}{c}\text { R } \\
\text { Square }\end{array}$ & $\begin{array}{c}\text { R Square } \\
\text { Adjusted }\end{array}$ \\
\hline $\begin{array}{c}\text { Kinerja Pegawai } \\
\text { (Y) }\end{array}$ & 0.824 & 0.820 \\
\hline $\begin{array}{l}\text { Sumber: Hasil Output PLS 3.0 } \\
\end{array}$
\end{tabular}

\section{Uji Hipotesis}

Dalam hasil pengolahan data, maka t tabel yang digunakan dalam penelitian ini ialah sebesar 1.66 yang didapatkan atau diperoleh dari rumus $\mathrm{df}=\mathrm{N}-\mathrm{k}$ atau $\mathrm{df}=88-3=85$, dan dengan suatu tingkat kepercayaan dalam penelitian yaitu sebesar $95 \%$ atau alpha sebesar 0,05 . Berdasarkan pada tabel 8, maka dapat disimpulkan bahwa output pengujian pada variabel Kompetensi yang dilakukan terhadap Kinerja Pegawai telah memiliki hubungan yang positif, dapat dikatakan sedemikian karena yang didasari dengan nilai original sample atau nilai korelasi dari variabel ini yaitu sebesar 0,748 . Selanjutnya, jika dilihat berdasarkan hasil pengolahan uji $\mathrm{t}$ statistik maka telah menunjukan bahwa $\mathrm{t}$ hitung $10,100>\mathrm{t}$ tabel 1,663. Hal ini dapat diartikan bahwa variabel Kompetensi memiliki pengaruh terhadap Kinerja Pegawai. Dengan nilai signifikan (P Values) sebesar $0,000<0,05$ yang telah menmbuktikan bahwa variabel Kompetensi berpengaruh dan dapat dinilai signifikan terhadap Kinerja Pegawai.

Berdasarkan pada tabel 8, dapat disimpulkan bahwa hasil dari pengujian pada variabel Pengalaman Kerja terhadap Kinerja Pegawai telah dapat dikatakan memiliki hubungan yang positif, Hal ini dapat dikatakan karena nilai original sample atau nilai korelasi yang didapat yaitu sebesar 0,190 . Jika dilihat dari hasil Pengolahan uji t statistik yang menunjukan t hitung 2,844 > t tabel 1,663, dan selanjutnya dapat diartikan bahwa variabel Pengalaman Kerja telah memiliki pengaruh terhadap Kinerja Pegawai. Dan demikian dengan nilai signifikan ( $\mathrm{P}$ Values) sebesar $0,005<0,05$ yang dapat menunjukkan bahwa variabel Pengalaman Kerja berpengaruh dan signifikan terhadap Kinerja Pegawai. 
Tabel 8. Uji t-Statistik

\begin{tabular}{lccc}
\hline & $\begin{array}{c}\text { Original } \\
\text { Sample (O) }\end{array}$ & $\begin{array}{c}\text { T Statistics } \\
(\mid \mathbf{O} / \text { STDEV|) }\end{array}$ & P Values \\
\hline Kompetensi (X1) -> Kinerja Pegawai (Y) & 0.748 & 10.100 & 0.000 \\
Pengalaman Kerja (X2) & 0.190 & 2.844 & 0.005 \\
-> Kinerja Pegawai (Y) & & & \\
\hline
\end{tabular}

Sumber: Hasil Output PLS 3.0

Berdasarkan hasil pengujian yang dilakukan oleh peneliti yaitu mengenai pengaruh Kompetensi dan Pengalaman Kerja terhadap Kinerja Pegawai pada pegawai KPP Pratama Jakarta Pancoran dengan bantuan metode Partial Least Square (PLS) dan software SmartPLS 3.0, berdasarkan hasil pengolahan dan dapat diperoleh hasil seperti sebagai berikut ini:

\section{Pengujian Kompetensi berpengaruh terhadap Kinerja Pegawai pada pegawai KPP Pratama Jakarta Pancoran}

Berdasarkan hasil penelitian dan pengolahan data yang telah dilakukan, maka hal ini menunjukkan bahwa hasil pengujian pada Hipotesis 1 (H1) menunjukkan bahwa variabel kompetensi mempunyai hubungan yang kuat dan positif dengan kinerja pegawai, hal ini didasarkan pada nilai original sample atau nilai korelasi yang sebesar 0.190. Berdasarkan hal tersebut, maka didapat hasil pengolahan uji ustatistik $\mathrm{t}$ menunjukkan bahwa t-hitung sebesar $10,100>\mathrm{t}$ tabel 1,663 dan telah memiliki nilai signifikan (P-values) sebesar $0,000<0,05$. Berdasarkan hal ini maka dapat disimpulkan bahwa Ho ditolak dan Ha diterima, serta dapat diartikan bahwa variabel kompetensi mempunyai pengaruh dan signifikan terhadap kinerja pegawai. Hal ini terlihat berdasarkan jawaban dari pernyataan responden yang rata-rata atau mayoritas setuju dan akan menjaga nilai-nilai yang dimiliki oleh perusahaan sesuai dengan hasil pernyataan paling tinggi sebesar ialah sebesar 0,874 yaitu pada K8, tetapi walaupun terdapat hasil pernyataan paling rendah yaitu sebesar 0,734 yaitu pada K11 yang berarti di KPP Pratama Jakarta Pancoran masih ada pegawai yang kurang kurang memiliki minat yang cukup baik atas pekerjaannya saat ini dan untuk meningkatkan kinerja kedepannya. Maka berdasarkan hal tersebut dapat disimpulkan bahwa para pegawai setuju kompetensi diperlukan agar dapat meningkatkan kinerja yang dimiliki oleh perusahaan dan untuk mengembangkan potensi diri seorang pegawai, walaupun di dalam pekerjaannya masih ada pegawai yang kurang memiliki minat dalam pekerjaannya tetapi karena tuntutan dari pekerjaannya maka mereka harus menyelesaikan dengan baik dan meningkatkan kinerja dari perusahaannya.

Kompetensi secara garis besar dapat berupa pengetahuan, pemahaman, kemampuan/keterampilan, nilai, sikap, dan minat. Dalam hal ini maka pengetahuan yang dimiliki oleh para pegawai KPP Pratama Jakarta Pancoran dapat dikatakan sudah sesuai atau memiliki kategori cukup memiliki pengetahuan mengenai job desk, penggunaan peralatan kantor dan dalam haal penyelesaian tugas. Selanjutnya ialah mengenai pemahaman seperti para pegawai di KPP Pratama Jakarta Pancoran telah memahami tanggung jawab dan tugas yang diberikan perusahaan kepadanya. Begitupula dengan kemampuan atau keterampilan yang dimiliki oleh para pegawai sudah sesuai dengan tugas dan pegawai dapat menyelesaikan masalah serta pekerjaannya. Dalam hal nilai, pegawai sudah sangat memahami nilai-nilai dalam perusahaan seperti bersikap profesional dalam bekerja dan menjaga nilai-nilai yang terkandung dalam perusahaan. Dalam hal sikap, para pegawai di KPP Pratama Jakarta Pancoran sudah menjunjung tinggi/menjaga sikap dalam menjalankan pekerjaannya seperti menjunjung sikap kejujuran, serta telah menaati norma dan aturan yang berlaku. Hal terakhir yaitu menyangkut minat pegawai dalam bekerja, walaupun dalam penelitian ini memiliki nilai terendah dalam pernyataan responden yang menunjukkan bahwa sebagian kecil pegawai kurang memiliki minat dalam bekerja atau bidangnya, dalam hal ini tetap lebih banyak atau sudah sebagian besar pegawai KPP Pratama Jakarta Pancoran memiliki minat dalam pekerjaanya dibidang perpajakan 
sehingga pegawai tetap mampu mengerjakan tugasnya dengan baik.

Demikian dapat disimpulkan bahwa Kompetensi memiliki pengaruh terhadap Kinerja Pegawai dikarenakan dalam melaksanakan pekerjaan dalam KPP Pratama Jakarta Pancoran diperlukan kompetensi yang perlu dimiliki oleh setiap pegawai, seperti halnya kejujuran, taat kepada norma atau aturan yang berlaku, dan dapat menyelesaikan pekerjaan sesuai dengan tugas yang ditugaskan kepada pegawai tersebut. Hal ini karena dengan adanya kompetensi yang unggul maka akan memiliki banyak bermanfaat bagi keberlangsungan perusahaan dan dengan kompetensi yang unggul maka pegawai dapat meningkatkan kinerja perusahaan. Hasil ini sesuai dengan prediksi atau pendugaan pada hipotesis yang telah dilakukan pada awal penelitian ini, dan hasil penelitian ini sesuai dengan penelitian sudah dilakukan oleh (Kolibácová, 2014), (Manani \& Ngui, 2019) dan oleh (Fransisca \& Adiputra, 2019) yaitu dalam hasil ini bahwa telah mendapati kesesuaian, bahwa terdapat hasil Kompetensi berpengaruh secara signifikan dan dikatakan berpengaruh kuat terhadap Kinerja Pegawai.

\section{Pengujian Pengalaman Kerja berpengaruh terhadap Kinerja Pegawai pada pegawai KPP Pratama Jakarta Pancoran}

Sesuai dari hasil penelitian dan pengolahan data yang telah dilakukan, maka hasil menunjukkan bahwa pengujian pada Hipotesis 2 (H2) menunjukkan bahwa variabel pengalaman kerja mempunyai hubungan yang kuat dan positif terhadap variabel kinerja pegawai, hal ini didasarkan pada nilai original sample atau nilai korelasi yang sebesar 0,748. Selanjutnya ialah hasil pengolahan uji statistik $\mathrm{t}$ menunjukkan bahwa nilai $\mathrm{t}$ hitung 2,844 > t tabel 1,663 dan dengan nilai signifikan $(P$ value) sebesar $0,005<0,05$. Berdasarkan hasil tersebut, maka dapat diambil kesimpulan bahwa Ho ditolak dan Ha diterima, serta dapat diartikan bahwa variabel pengalaman kerja mempunyai pengaruh dan dapat dinilai signifikan terhadap kinerja karyawan.

Berdasarkan hal tersebut maka jawaban dari pernyataan responden yang mayoritas atu rata-rata telah setuju bahwa memiliki dengan memiliki pengalaman kerja yang memumpuni atau cukup maka akan membantu memudahkan dalam melaksanakan atau menyelesaikan pekerjaan, hal ini sesuai dengan nilai yang tertinggi yaitu sebesar 0,897 pada pernyataan PK5 / pernyataan mengenai pengalaman kerja nomor 5 dan hasil dengan nilai terendah sebesar 0,776 pada pernyataan PK3 / pernyataan mengenai pengalaman kerja nomor 3 , dengan pernyataan responden mengenai rutinitas pekerjaan yang dimana para pegawai perlu meningkatkan rutinitas pekerjaan yang telah diberikan, agar mampu menyelesaikannya dengan baik pada lain waktu atau menyelesaikan pekerjaan selanjutnya. Berdasarkan kedua hal tersebut maka pegawai KPP Pratama Jakarta Pancoran Jakarta rata-rata sudah memiliki pengalaman yang dinilai "cukup" sebagai pegawai, karena rata-rata sudah memiliki masa kerja walaupun masa kerjanya lebih banyak <10 Tahun, dan pegawai dapat menyelesaikan pekerjaan dengan mudah jika diberikan rutinitas atau secara terusmenerus mengenai pekerjaan tersebut.

Pengalaman kerja dalam penelitian ini mencakup masa kerja, tingkat rutinitas pekerjaan, dan kemampuan melaksanakan pekerjaan. Berdasarkan indikator tersebut masa kerja pegawai di KPP Pratama Jakarta Pancoran sudah dikatakan mencukupi atau telah sesuai dengan yang dibutuhkan KPP Pratama Jakarta, walaupun masa kerja paling banyak $<10$ tahun, tetapi sudah dapat dikatakan cukup, karena dengan masa kerja seperti itu pegawai tetap dapat memahami, dan menyelesaikan pekerjaan dengan memanfaatkan pengalaman mereka dalam bekerja. Selanjutnya pegawai di KPP Pratama Jakarta Pancoran berpendapat bahwa tingkat rutinitas pekerjaan juga berpengaruh terhadap kinerja pegawai, walaupun memiliki nilai loading factor terendah dalam indikator ini yang membuktikan bahwa sebagian pegawai merasa bahwa KPP Pratama Jakarta Pancoran perlu meningkatkan pemberian rutinitas pekerjaan agar pegawai mampu menyelesaikan pekerjaan dengan baik dan benar. Hal terakhir yaitu mengenai kemampuan seorang pegawai dalam menjalankan pekerjaannya, pegawai KPP Pratama Jakarta Pancoran setuju bahwa pegawai mampu menyelesaikan pekerjaannya secara baik dan maksimal dengan memanfaatkan kemampuan yang dimilikinya.

Maka berdasarkan hasil ini, dapat disintesakan bahwa Pengalaman Kerja berpengaruh terhadap Kinerja Pegawai 
dikarenakan dalam pelaksanaan suatu pekerjaan terkadang diperlukan minimal atau kualifikasi pengalaman yang dimiliki, hal ini terjadi karena dengan adanya pegawai yang memiliki pengalaman kerja tertentu dapat mengerti dan menjalankan segala tugas yang diberikan dengan baik sehingga secara tidak langsung juga mampu membantunya dalam meningkatkan kinerja, baik kinerja individu kinerja perusahaan. Hal ini juga berlaku bagi pengambilan keputusan, karena pegawai yang memiliki pengalaman kerja yang memumpuni atau cukup maka dapat mengambil keputusan dengan baik dan sesuai. Hal-hal di atas dapat diperoleh dengan cara memberikan pelatihan dan pengembangan dalam hal sumber daya manusia, baik untuk jangka pendek atau jangka panjang.

Berdasarkan hasil tersebut, maka hal ini sejalan dengan pendugaan hipotesis pada awal penelitian ini yang dilakukan oleh peneliti. Hasil penelitian ini juga sesuai atau sudah sejalan dengan penelitian yang dilakukan oleh Gunawan et al. (2017); Hasudungan (2017), dan oleh Anjani \& Wirawati (2018) yaitu Pengalaman Kerja berpengaruh secara positif dan dapat dikatakan sudah signifikan terhadap Kinerja Pegawai.

\section{KESIMPULAN}

Berdasarkan penelitian yang dilakukan dengan menggunakan SmartPLS 3.0 dan menerima analisis data serta pembahasan yang dijelaskan pada pembahasan bab sebelumnya, khususnya mengenai pengaruh Kompetensi, Pengalaman Kerja terhadap kinerja pegawai KPP Pratama Jakarta Pancoran, sehingga dapat diambil kesimpulan sebagai berikut:

1. Kompetensi memiliki hubungan yang positif dan dinilai sudah berpengaruh secara signifikan terhadap Kinerja Pegawai. Kesimpulan ini dapat dilihat berdasarkan pada hasil jawaban responden yang menunjukkan bahwa mayoritas para pegawai setuju bahwa kompetensi diperlukan agar dapat meningkatkan kinerja yang dimiliki oleh perusahaan dan untuk mengembangkan potensi diri seorang pegawai, walaupun di dalam pekerjaannya masih ada pegawai yang kurang memiliki minat dalam pekerjaannya tetapi karena tuntutan dari pekerjaannya maka mereka harus menyelesaikan dengan baik dan untuk meningkatkan kinerja dari perusahaannya. Maka, dapat dikatakan jika kompetensi berpengaruh terhadap kinerja pegawai dikarenakan dalam bekerja tidak hanya cukup bagi pegawai untuk hanya memiliki atau mengandalkan satu kemampuan atau keterampilan dalam bekerja, karena diperlukan beberapa kompetensi yang dibutuhkan oleh perusahaan untuk mengisi jabatan tertentu dan untuk meningkatkan kinerja perusahaan, hal ini juga berhubungan dengan sikap dan nilai yang dianut dalam KPP Pratama Jakarta Pancoran, bahwa setiap pegawai perlu memiliki sikap kejujuran dan selalu menjunjung tinggi nilai yang dimiliki perusahaan. Pegawai perlu selalu memiliki kejujuran, karena dalam bidang perpajakan ini diperlukan kejujuran karena sangat rawan terhadap kasus korupsi. Dalam hal ini perlu adanya kompetensi yang unggul yang akan memiliki banyak bermanfaat bagi perusahaan, karena masukan hasil kerja pegawai sangat berpengaruh terhadap kinerja dan keberlangsungan hidup perusahaan.

2. Pengalaman Kerja dinilai telah memiliki hubungan yang positif dan berpengaruh signifikan terhadap Kinerja Pegawai. Kesimpulan ini dapat dilihat berdasarkan pada hasil jawaban responden yang menunjukkan bahwa para pegawai setuju jika pengalaman kerja yang mereka miliki sudah sesuai dengan kualifikasi dalam pengisian jabatan atau dalam pelaksanaan tugas yang diberikan oleh perusahaan dan pegawai setuju bahwa untuk pengambilan keputusan, pegawai yang memiliki pengalaman kerja yang mumpuni atau cukup maka dapat mengambil keputusan dengan baik dan sesuai oleh kondisi perusahaan. Maka, dapat dikatakan bahwa pengalaman kerja berpengaruh terhadap kinerja pegawai dikarenakan tidak cukup bagi pegawai jika hanya mengandalkan pada pengetahuan yang dimiliki tanpa adanya pengalaman kerja, pemahaman pekerjaan dan rutinitas pekerjaan sehingga dapat menghambat dalam menyelesaikan pekerjaannya. Perusahaan juga perlu memberikan pelatihan dan pengembangan terhadap pegawainya agar meningkatkan kinerja serta 
pemahaman pegawai dalam melaksanakan pekerjaan. Dikarenakan pekerjaan tersebut harus diselesaikan dengan baik dan sesuai karena hasil kerja pegawai sangat berpengaruh terhadap kinerja dari perusahaan.

\section{SARAN}

Berdasarkan kesimpulan di atas, berikut ialah saran yang dapat dibuat dan diberikan berdasarkan hasil penelitian tersebut:

1. Peneliti dapat memberikan saran kepada KPP Pratama Jakarta Pancoran berdasarkan hasil dari kesimpulan terkait permasalahan kompetensi pada perusahaan ini agar dapat lebih memperhatikan terkait tingkat kompetensi pegawai dalam melaksanakan pekerjaan. KPP Pratama Jakarta Pancoran perlu meningkatkan kompetensi dalam hal minat para pegawai dalam melaksanakan pekerjaan dan perlu mempertahankan nilainilai yang dianut oleh perusahaan serta pegawai, karena dengan mempertahankan nilai atau sikap dalam pekerjaannya pegawai mampu senantiasa untuk bersikap jujur dan selalu memaksimalkan/memberikan yang terbaik dalam pekerjaannya, apalagi dalam bidang perpajakan sangat rawan bagi kasus korupsi, sehingga perusahaan perlu menjaga sikap kejujuran dari para pegawainya dan membuat para pegawai selalu menjunjung tinggi nilai perusahaan. Serta cara para pegawai dalam menyelesaikan pekerjaannya, perusahaan juga dapat membantu meningkatkan kompetensi dengan memberikan pelatihan dan pengembangan untuk memahami dan meningkatkan kompetensi pegawai dalam menyelesaikan pekerjaan dengan berbagai

\section{DAFTAR REFERENSI}

Anjani, P. W., \& Wirawati, N. G. P. (2018).

Pengaruh Usia, Pengalaman Kerja,

Tingkat Pendidikan , dan Kompleksitas

Tugas terhadap Efektivitas Pengguna

Sistem Informasi Akuntansi. E-Jurnal

Akuntansi Universitas Udayana, 22, 2430-2457.

Bintoro, M. .., and Daryanto. 2017.

Manajemen Penilaian Kinerja tingkat kesulitan, agar para pegawai dapat maksimal dalam menyelesaikan pekerjaannya dan mampu meningkatkan kinerja perusahaan.

2.Peneliti dapat memberikan saran kepada KPP Pratama Jakarta Pancoran berdasarkan hasil dari kesimpulan terkait permasalahan Pengalaman Kerja pada perusahaan ini agar lebih memerhatikan terkait dengan pengalaman kerja dari pegawai, dalam hal ini adalah masa kerja pegawai, dimana masa kerja pegawai yang tergolong cukup atau tergolong sudah berpengalaman dapat meningkatkan kinerja perusahaan dengan pegawai yang memiliki pengalaman kerja dapat dengan mudah melaksanakan dan menyelesaikan pekerjaannya. Selanjutnya ialah perlu melakukan pelatihan dan pengembangan sumber daya manusia baik dalam jangka pendek ataupun jangka Panjang, karena hal ini dapat menguntungkan perusahaan dalam menghasilkan pegawai atau sumber daya manusia yang berkualitas.

Dengan adanya pengalaman dan rutinitas yang telah dilaluinya maka dapat diberikan pekerjaan yang sesuai dengan pengalamannya, karena pegawai yang telah memiliki masa kerja dan pengalaman maka dapat mengambil keputusan dengan baik dan sesuai. Serta perusahaan perlu memperhatikan kualifikasi pengalaman yang dimiliki pegawainya ataupun dalam jabatan tertentu, dengan begitu maka pegawai yang memiliki pengalaman kerja tertentu dapat mengerti dan menjalankan pekerjaannya dengan baik sehingga akan meningkatkan kinerja pegawai serta kinerja perusahaan, karena dalam KPP Pratama Jakarta Pancoran selalu diwajibkan untuk selalu meningkatkan kinerja dalam pelayanan pajak untuk meningkatkan pemasukan negara melalui pajak.

Karyawan. 1st ed. Yogyakarta: Penerbit GAVA Media.

Coulter, Robbins. 2016. Manajemen. 13th ed. Jakarta: Erlangga.

Fransisca, M., \& Adiputra, I. G. (2019). Pengaruh Pengalaman Kerja dan Kompetensi Terhadap Kinerja Karyawan di PT. Naga Samudera. Jurnal Manajerial Dan Kewirausahaan, I(4), 900-908. 
Gunawan, W. F., Nurwati, \& Nasrul. (2017). Pengaruh Kompetensi, Pengalaman Kerja Dan Lingkungan Kerja Terhadap Kinerja Pegawai (Effect of Competence, Work Experience and Work Environment on Employee Performance. Jurnal Manajemen, Bisnis Dan Organisasi (JUMBO), 1(2), 1-9. https://doi.org/10.24912/jmbk.v4i3.7922

Hasudungan, L. (2017). Pengaruh Faktor Pendidikan, Umur Dan Pengalaman Kerja Terhadap Kinerja Aparatur Sipil Negara (Asn) Pada Dinas Pekerjaan Umum Penata Ruang, Perumahan Dan Kawasan Permukiman Kabupaten Kapuas Kalimantan Tengah. Jurnal Ilmiah Ekonomi Bisnis, 3 No.3, 301310.

Iman, G. (2014). Structural Equation Modeling Metode Alternatif Dengan Partial Least Squares (PLS) (4th ed.). Semarang.: Badan Penerbit Universitas Diponegoro.

Kolibácová, G. (2014). The relationship between competency and performance. Acta Universitatis Agriculturae et Silviculturae Mendelianae Brunensis, 62(6), 1315-1327. https://doi.org/10.11118/actaun2014620 61315

Manani, E., \& Ngui, T. K. (2019). Effects of Employee Competencies on Employee Job. Global Scientific Journals, 7(10), 1688-1702.
Octavianus, Wungow Raymond, and Adolfina. 2018. "Pengaruh Pengalaman Kerja Dan Pelatihan Kerja Terhadap Kinerja Karyawan Pt. Telkom Indonesia Cabang Manado.” Jurnal EMBA: Jurnal Riset Ekonomi, Manajemen, Bisnis Dan Akuntansi 6(3): 1758 - 1767. doi: 10.35794/emba.v6i3.20445.

Paramitha, Megazade Novrina. 2015. "Pelaksanaan Rekrutmen Karyawan Pada Btn Cabang Surabaya." 53(9):1689-99.

Ukkas, I. (2017). Faktor-Faktor Yang Mempengaruhi Produktivitas Tenaga Kerja Industri Kecil Kota Palopo. Kelola: Journal of Islamic Education Management, 2(2). https://doi.org/10.24256/kelola.v2i2.440

Rialmi, Zackharia, and Papang Patoni. 2020. "Pengaruh Pengembangan Karir Terhadap Kinerja Karyawan Pada PT Bank CIMB Niaga Cabang Pondok Indah, Jakarta Selatan.” Jurnal Mandiri : Ilmu Pengetahuan, Seni, Dan Teknologi 4(2):210-21. doi:

10.33753/mandiri.v4i2.129.

Suwarno, and Ronal Aprianto. 2019. "Pengaruh Pengalaman Kerja Dan Pengembangan Karir Terhadap Kinerja Karyawan Pada Pt Sinar Niaga Sejahtera Kota Lubuklinggau.” Jurnal Ilmiah Ekonomi Bisnis 24(1).i

\section{Copyrights}

Copyright for this article is retained by the author(s), with first publication rights granted to the journal.

This is an open-access article distributed under the terms and conditions of the Creative Commons Attribution license (http://creativecommons.org/licenses/by/4.0/). 